\title{
MONITORING GPS
}

\author{
Marcin Bigoraj, Kamil Kaźmierak, Mateusz Krupa, Ewelina Narejko, Rafał Pytka \\ Politechnika Lubelska, Wydział Elektrotechniki i Informatyki
}

Streszczenie. Artykut opisuje budowę i działanie aplikacji monitorujacej położenie urzadzenia mobilnego w terenie wykorzystując wbudowany modut GPS Opisuje sposób prezentacji zebranych danych przy pomocy dedykowanej aplikacji webowej oraz obrazuje jej możliwości.

Slowa kluczowe: GPS, monitoring, śledzenie, Android, ASP.NET, Google Maps API, Comarch ERP

\section{GPS MONITORING}

Abstract. The article describes construction and performance of mobile application monitoring position of the mobile device using the built-in GPS. Describes the presentation of the collected data using dedicated web application and demonstrates its capabilities.

Keywords: GPS, monitoring, tracking, Android, ASP.NET, Google Maps API, Comarch ERP

\section{Wstęp}

Dynamiczny rozwój technologii w XXI wieku dotknął każdej sfery życia ludzkiego. Bez względu na czas i miejsce, nie istnieją ograniczenia w przemieszczaniu się i komunikacji międzyludzkiej. Zjawiska te w szczególny sposób odbiły się na biznesie, gdzie pracownik przebywający poza biurem nie jest obecnie zdany na samego siebie, ma nieograniczony dostęp do informacji jak i kontakt $\mathrm{z}$ centralą firmy.

Niestety zwierzchnik nie zawsze może pozwolić sobie na pełną kontrolę pracowników przemieszczających się po dużym obszarze. Im jest ich więcej, tym posiada mniejszą kontrolę nad ich poczynaniami. O ile sprawniejsza byłaby ich praca, gdyby miał możliwość sprawdzić położenie wszystkich pracowników jednocześnie, za pomocą jednego narzędzia. Ile łatwiejsze stałoby się rozstrzyganie kwestii spornych, jeżeli istniałby niemożliwy do podważenia zbiór danych, zawierający dokładną lokalizację i czas pobytu podwładnych, odtwarzający ich trasy sprzed wielu miesięcy czy lat, której koszty nie wiązałyby się $\mathrm{z}$ ilością monitorowanych pracowników.

\section{Idea dzialania systemu}

Zaimplementowany przez nas system ma na celu umożliwienie pracodawcy monitoringu pracowników działających $\mathrm{w}$ terenie. W związku $\mathrm{z}$ naporem nowych technologii i wciąż rosnącym zainteresowaniem dotyczącym urządzeń mobilnych, to właśnie na nich został oparty projekt systemu.

Aktualnie najpopularniejszym systemem operacyjnym na smartphony i tablety jest platforma Android. W ciągu kilku lat znacząco opanowała rynek telefonii komórkowej, oferując swoim użytkownikom bogaty zestaw aplikacji dostępnych w sklepie Google Play oraz zestaw darmowych narzędzi programowania dla ich twórców.

Rozwój technologii i powszechnej miniaturyzacji od wielu lat wpływa na skupianie wielu elementów funkcjonalnych w jednym urządzeniu. Dzisiejszy telefon nie służy jedynie do wykonywania połączeń, czy pisania krótkich wiadomości SMS. Został on zaopatrzony m. in. w akcelerometr, mechanizmy umożliwiające połączenie $\mathrm{z}$ siecią Internet czy moduł GPS. $\mathrm{Na}$ bazie dwóch ostatnich modułów $\mathrm{w}$ prosty sposób można zaiplementować część mobilną systemu [3].

Podążając ideą mobilności stwierdziliśmy, iż pracodawca również nie powinien być skazany na przebywanie w biurze, aby móc monitorować pracę podwładnych. Dlatego obserwację pracowników i ich położenia zaimplementowano w postaci aplikacji webowej, dostępnej $\mathrm{z}$ poziomu przeglądarki internetowej. Aby sprostać wymaganiom klientów biznesowych została ona zaimplementowana przy użyciu technologii ASP.NET.

\section{Zapisywanie lokalizacji}

Zapis danych na urządzeniu mobilnym powinien funkcjonować bez znaczącej ingerencji użytkownika. W tym celu został zaimplementowany serwis sczytujący położenie i zapisujący je do lokalnej bazy danych. Takie rozwiązanie nie posiada interfejsu użytkownika, a samo zainicjowanie czy zakończenie zapisu trasy jest tożsame $\mathrm{z}$ włączeniem i wyłączeniem odbiornika GPS w telefonie komórkowym. Dzięki mechanizmowi zapisu do lokalnej bazy danych gwarantujemy poprawne funkcjonowanie aplikacji zarówno online jak i offline.

Usługa startowana jest w momencie pierwszego uruchomienia aplikacji, a w przypadku wyłączenia telefonu, po jego ponownym włączeniu. Działa więc przez cały czas, gdy telefon jest aktywny i w każdym momencie możliwy jest odbiór nowych danych. Dzięki takiemu rozwiązaniu użytkownik nie musi pamiętać o każdorazowym włączeniu aplikacji.

W celu aktualizacji położenia użytkownika, serwis implementuje interfejs LocationListener. Jedną z metod, których dostarcza, jest onLocationChanged(), wywoływana w przypadku uzyskania nowych współrzędnych z modułu GPS. Właśnie wtedy zapisywane są nowe informacje. Ważny element stanowi dobór odpowiednich parametrów zapisu trasy (czasu i odległości między kolejnymi odbieranymi punktami). Konieczne jest znalezienie kompromisu między dokładnością rejestracji trasy, a korzyściami wynikającymi $\mathrm{Z}$ oszczędzania baterii urządzenia mobilnego. W trakcie testów ustaliliśmy następujące wartości: odległość 150 metrów, czas 15 sekund.

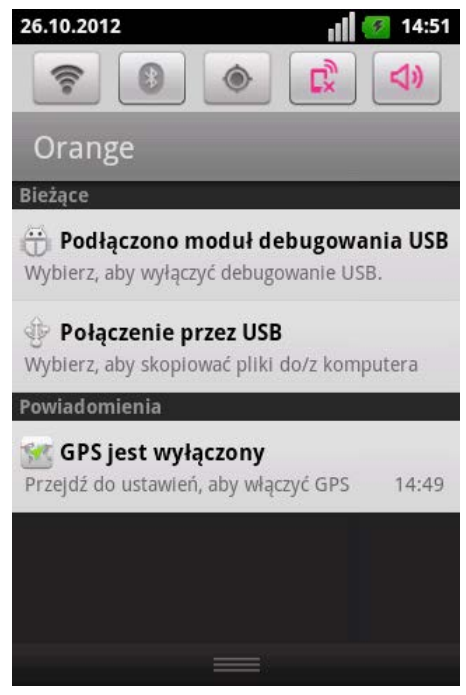

Rys. 1. Powiadomienie o konieczności włączenia modutu GPS 
Dodaliśmy również powiadomienie o konieczności włączenia modułu GPS (rys. 1). Użytkownik samodzielnie może zdecydować czy powinno być widoczne na pasku statusu systemu Android i ma możliwość jego wyłączenia. Po kliknięciu na zakładke z przypomnieniem zostaje uruchomiona aktywność lokalizacji i zabezpieczeń systemu Android (rys. 2), gdzie w łatwy sposób można dokonać zmian w ustawieniach i włączyć potrzebne moduły.

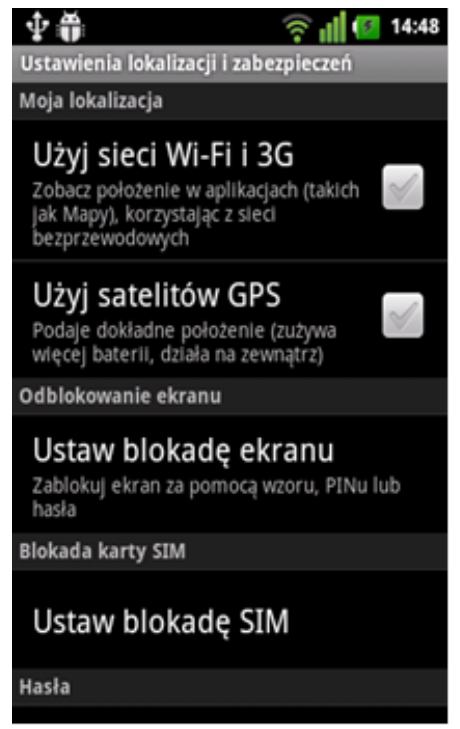

Rys. 2. Ustawienia lokalizacji i zabezpieczeń systemu Android

Rodzajem systemu GPS wykorzystywanym w telefonii komórkowej jest A-GPS (ang. Assisted GPS). W przypadku dostępności systemu u operatora, usługa wykorzystując infrastrukturę operatorów GPS potrafi ustalić lokalizację urządzenia w ciagu 2-3 sekund. Trzeba wspomnieć, iż pobranie pierwszych współrzędnych geograficznych lub brak dostępności systemu u operatora może wydłużyć tan czas wielokrotnie [1].
Do gromadzenia danych na urządzeniu mobilnym stworzona została tabela zawierająca pola służące do przechowywania długości i szerokości geograficznej, czasu odebrania współrzędnych oraz kolumnę informującą czy dane zostały przesłane na zewnętrzny serwer.

\section{Synchronizacja danych}

Aplikacja implementuje mechanizmy umożliwiające synchronizację i przesyłanie zgromadzonych danych na serwer zewnętrzny. Również w tym przypadku wykorzystaliśmy usługę systemu Android. Serwis startowany jest w momencie wykrycia uzyskania połączenia $z$ Internetem. Tworzone jest nowe zadanie i co 2 minuty następuje próba przesłania nowych współrzędnych, o ile takie istnieją. Ustalenie odpowiedniego czasu pozwoliło oszczędzać baterię urządzenia mobilnego, a jednocześnie zapewnić możliwość podglądu aktualnego położenia użytkowników na stronie WWW.

Zapisane punkty wysyłane są $\mathrm{z}$ wykorzystaniem formatu tekstowej wymiany danych JSON. JSON swoją popularność zawdzięcza prostej reprezentacji struktur danych powszechnie stosowanych w wielu językach programowania. Do najczęściej wykorzystywanych formatów danych należą: typy proste, listy oraz wartości składające się $\mathrm{z}$ pary klucz-wartość. Format umożliwia przedstawienie danych w sposób naturalny, łatwy do odczytu. Nie wprowadza przy tym nieścisłości w odwzorowaniu między ich wewnętrzną implementacją w języku programowania, a postacią tekstową. Dzięki temu możliwe staje się łatwe przekształcanie łańcuchów znaków zakodowanych formatem JSON do postaci obiektów i odwrotnie [4].

$\mathrm{W}$ momencie uruchomienia serwisu usuwane są również dane, które zostały pomyślne przesłane. Dzięki temu zapobiegamy gromadzeniu nadmiarowych informacji w bazie danych telefonu.

Kiedy system wykryje utratę połączenia $\mathrm{z}$ siecią, wówczas usługa jest zatrzymywana. W takiej sytuacji próba wysłania uzyskanych punktów jest bezcelowa, a aplikacja nie zabiera niepotrzebnie zasobów systemu innym uruchomionym procesom.

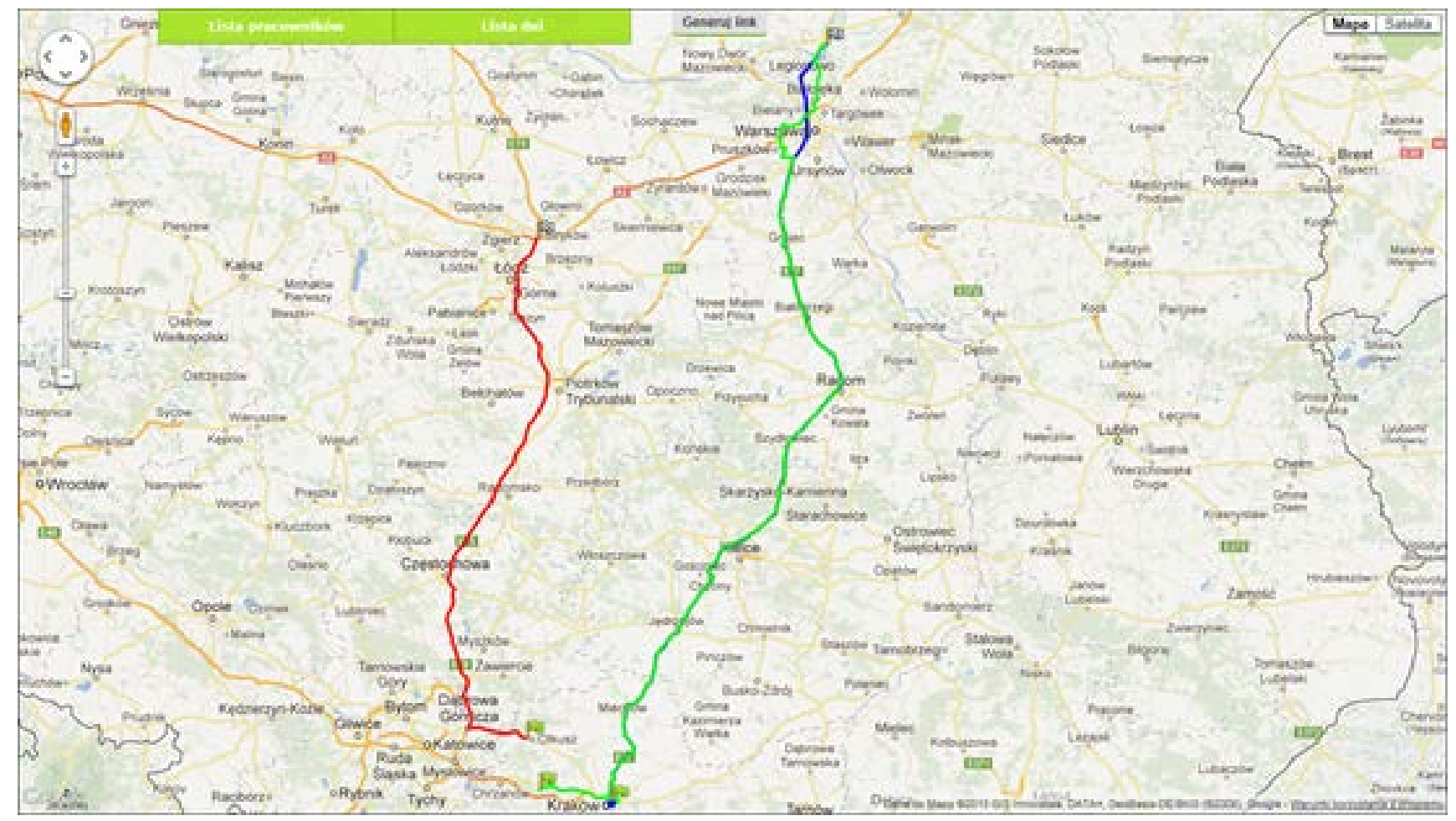

Rys. 3. Reprezentacja tras zarejestrowanych w czasie jednego dnia 


\section{Aplikacja webowa}

Celem aplikacji internetowej było udostępnienie pracodawcy narzędzia, za pomocą którego miałby możliwość monitorowania swoich pracowników. Tworząc stronę wzorowaliśmy się na sportowej aplikacji Endomondo, której przeznaczenie jest inne, jednak sposób prezentacji tras jest niemalże jednakowy. Chcieliśmy również wyeliminować pewne wady Endomondo oraz dopasować profil naszej aplikacji do klientów biznesowych.

Do dyspozycji pracodawcy została oddana strona internetowa, która nie wymaga przeładowywania, gdyż cała treść jest tworzona i zastępowana dynamicznie. Jest to możliwe, dzięki zastosowaniu technologii AJAX. Podejście to umożliwiło sprawienie wrażenia użytkowania aplikacji internetowej, dostępnej w przeglądarce, zamiast zwykłej strony internetowej. Wyeliminowało też jedną z największych wad Endomondo - konieczność przewijania strony w dól, po wybraniu nowej trasy.

Dzięki zastosowaniu technologii ASP.NET MVC3, będącego implementacją wzorca strukturalnego Model-View-Controller, uzyskaliśmy przejrzystość kodu. Trasy rysowane są w języku JavaScript za pomocą API, udostępnionego przez Google. Wywołanie funkcji rysujących odbywa się w widoku, jednakże odpowiednie dane są wybierane i dostarczane przez kontroler.

Prawie cały ekran aplikacji stanowi mapa Google. Pierwszy widok, z jakim zetknie się użytkownik, zależy od stanu bazy danych $\mathrm{w}$ aktualnym dniu. Jeśli nie zostało zarejestrowane położenie jakiegokolwiek pracownika w obecnym dniu, zostanie wyświetlona mapa Polski. Jednakże, gdy do bazy danych trafi choć jeden punkt $\mathrm{z}$ aktualnego dnia, użytkownik ujrzy znacznik na mapie. Liczba znaczników na mapie zależy od liczby pracowników, którzy rozpoczęli już swoje trasy (rys. 4). Pozycje przedstawicieli handlowych są na bieżąco aktualizowane. Zostało to zrealizowane za pomocą żądań AJAX, wykonujących się w tle, co zadany czas (domyślnie 2 sekundy). Każde takie żądanie wysyła do serwera identyfikator pracownika oraz datę ostatniego punktu. Jeśli w bazie danych nie istnieją nowsze punkty, nic się nie stanie. W innym przypadku, zostanie zwrócony widok, zawierający funkcje JavaScript, usuwające stary znacznik i dodające nowy.

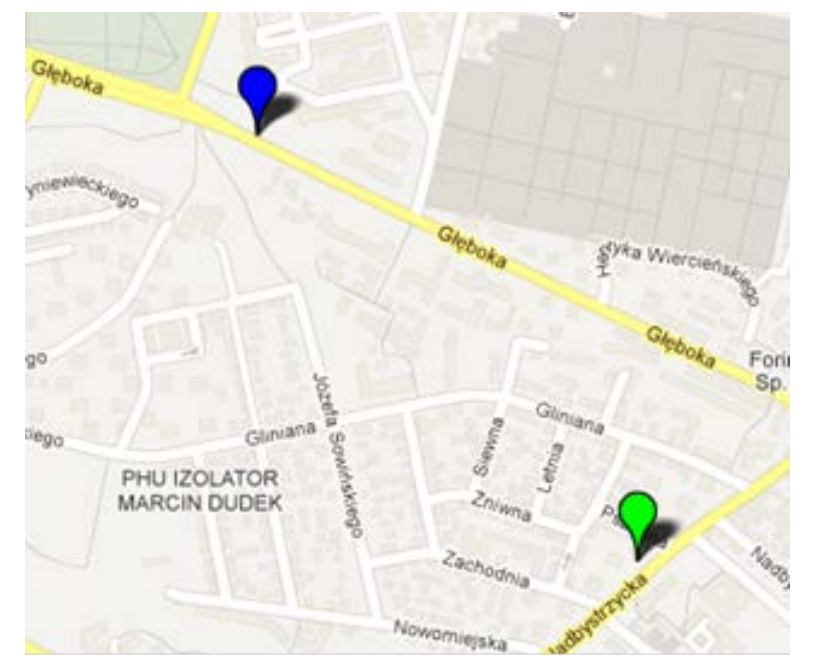

Rys. 4. Widok aktualnych pozycji

Pracodawca może także rozwinąć jedną $\mathrm{z}$ dwóch list (pracowników oraz dat), dających dostęp do historii. Po kliknięciu na link, znajdujący się na liście dat, zostanie wygenerowany widok, zawierający wszystkie trasy dla wybranego dnia (rys. 3). Trasy poszczególnych pracowników różnią się od siebie kolorem. Jeśli wybrano aktualną datę, trasy będą automatycznie dorysowywane, jak tylko pojawią się nowe punkty $\mathrm{w}$ bazie danych. Po kliknięciu na trasę, w miejscu kursora zostanie rozwinięta lista opcji, zawierająca także identyfikator pracownika. Implementując tę funkcję, kierowaliśmy się rozwiązaniami dostępnymi w systemach operacyjnych. Większość użytkowników korzysta z systemów z rodziny Windows, gdzie schowanie listy opcji następuje albo po wybraniu jednej z nich, albo po kliknięciu poza listę, dlatego nie chcieliśmy tworzyć nie intuicyjnych rozwiązań. Jedną z opcji do wyboru jest wyświetlenie pojedynczej trasy. Jest to skrót, gdyż taki sam rezultat można uzyskać po wybraniu przedstawiciela handlowego z listy pracowników, a następnie klikając na odpowiednią datę.

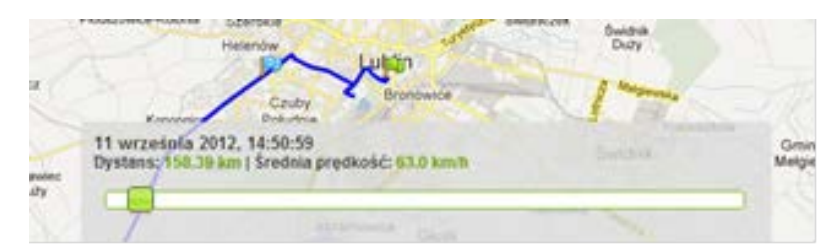

Rys. 5. Belka informacyjna

Widok pojedynczej trasy wprowadza dodatkowe możliwości, a mianowicie belkę informacyjną (rys. 5). Jest to stosunkowo niewielki obszar na dole ekranu, zawierający szczegóły danej trasy. Możliwe jest odczytanie identyfikatora pracownika, przebytego dystansu, średniej prędkości oraz daty pierwszego punktu. W przyszłości, gdy aplikacja zostałaby połączona z systemami firmy Comarch S.A., możliwe jest zastąpienie identyfikatora imieniem i nazwiskiem pracownika, oraz wprowadzenie dodatkowych danych na belce informacyjnej (np. ilości zawartych umów handlowych w danym dniu). Na belce znajduje się także suwak, którego przesuwanie powoduje wyświetlenie się flagi na mapie oraz aktualizację pola daty. Funkcja ta umożliwia dokładne sprawdzenie gdzie znajdował się pracownik w konkretnej godzinie.

Zastosowanie technologii AJAX powoduje, że nie jest możliwe uzyskanie linku prowadzącego do konkretnego widoku. Wszystkie dane aktualizacyjne przesyłane są w tle, co powoduje płynniejsze działanie systemu. Jeśli użytkownik chciałby udostępnić trasę innej osobie lub zapisać link prowadzący do wybranego widoku, stworzyliśmy możliwość wygenerowania takiego adresu URL. Po kliknięciu przycisku „Generuj link” otworzone zostanie okno z odpowiednim adresem (rys. 6).

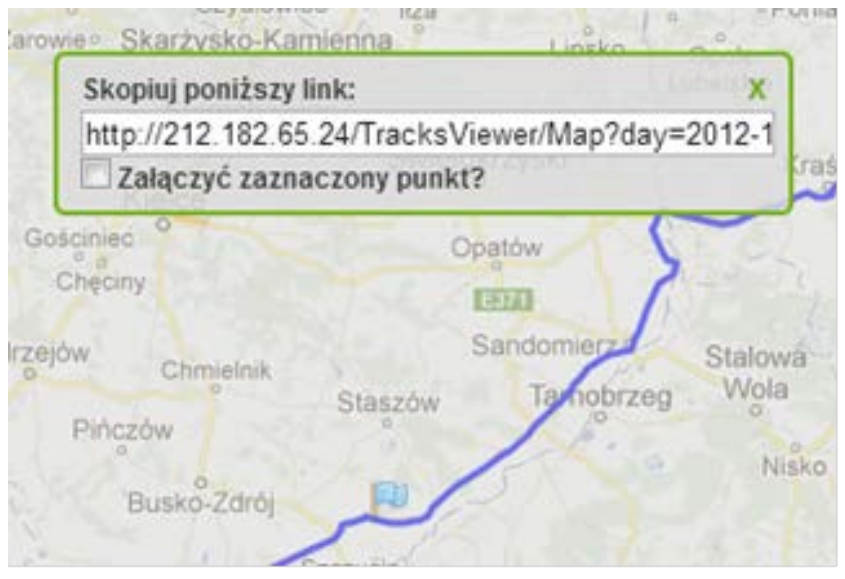

Rys. 6. Generator linków

\section{Google Maps API}

Google Maps API jest udostępnionym przez firmę Google interfejsem aplikacji Google Map, czyli nowoczesnego i zaawansowanego serwisu internetowego, który udostępnia oglądanie map i zdjęć lotniczych Ziemi. Dzięki API programiści mogą wykorzystać stworzone przez firmę Google mapy we własnych aplikacjach. W aplikacji webowej została wykorzystana 3 wersja Maps JavaScript API, która została zapowiedziana podczas konferencji Google I/O w maju 2009 roku.

Praca $\mathrm{z}$ wykorzystaniem map na własnej stronie wygląda bardzo dynamicznie, przez co może się wydawać, iż Google Maps 
wykorzystuje bardzo złożone technologie. W rzeczywistości wyświetlanie map bazuje na technologiach HTML, CSS i JavaScript, których użycie w danym przypadku sprowadza się do dość prostych działan.

Wyświetlana mapa jest złożona $\mathrm{z}$ kwadratowych obrazów, które zostają wyświetlone $\mathrm{w}$ tle za pomocą technologii Ajax i wstawione do znaczników <div> języka HTML. Podczas poruszania się po mapie, czyli zmiany aktualnego widoku, API przesyła informacje o nowym położeniu i przybliżeniu mapy, po czym Ajax zwraca i umieszcza na stronie nowe obrazki.

\section{Perspektywy rozwoju}

W celu umożliwienia monitoringu wielu jednostek mobilnych, a tym samym elastycznej rozbudowy istniejącego już systemu, została wprowadzona możliwość identyfikowania urządzenia mobilnego za pomocą indywidualnego numeru identyfikującego. Jego ustawienie może odbyć się w dwojaki sposób:

- programowo, dokonując niewielkich edycji w kodzie serwisu synchronizującego dane z serwerem zewnętrznym przed każdą instalacją oprogramowania;

- dokonując integracji mobilnej części programu z innymi aplikacjami dedykowanymi na urządzenia mobilne z systemem operacyjnym Android.

To drugie podejście otwiera przed systemem ogromne możliwości rozwoju. Wykorzystała je firma Comarch S.A. właściciel omawianego systemu monitorującego, rozbudowując Comarch ERP Mobilny Sprzedawca poprzez dodanie modułu pobierającego aktualne położenie.

Firma Comarch S.A. jest globalnym dostawca biznesowych rozwiązań IT [2]. Stworzyła ona zespół aplikacji w znaczącym stopniu ułatwiajacych zarzadzanie przedsiębiorstwem. Dokonując wdrożenia systemu monitorującego i łącząc go $\mathrm{z}$ wewnętrznymi bazami danych innych produktów, został stworzony jednolity system usprawniający pracę przedstawicieli handlowych i ich obserwację w terenie [5].

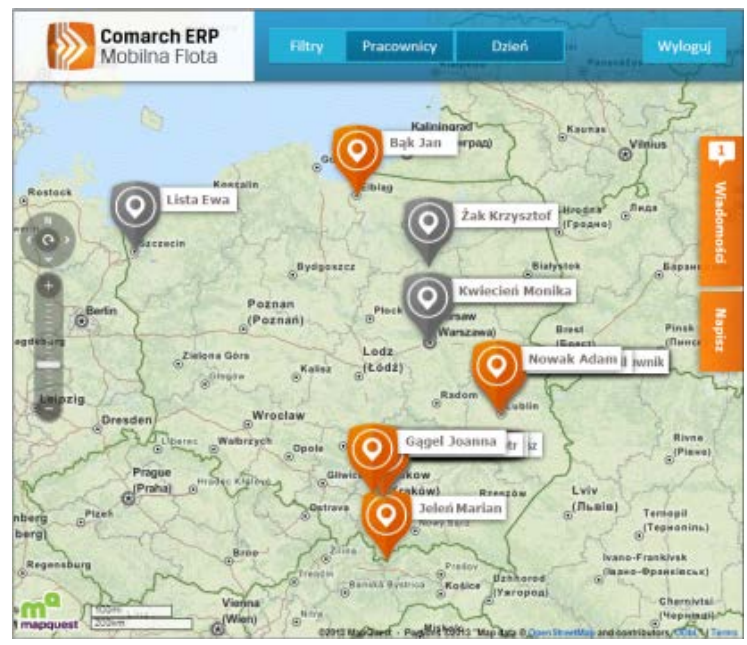

Rys. 7. Comarch ERP Mobilna Flota [5]

\section{Wnioski}

W czasach kiedy odległość przestaje być jakąkolwiek przeszkodą dla współczesnego człowieka, zaś technologię stwarzaja wciąż nowsze możliwości aplikacja taka jak monitoring sprawdza się w wielu dziedzinach życia. Zastosowanie jej do monitorowania pracowników, które wdrożyła firma Comarch S.A. w aplikacji Comarch ERP Mobilna Flota, jest jedynie niewielką częścią jej możliwości.

System w łatwy sposób może zostać zaimplementowany w całkiem odmiennych celach jak biznesowych. Może służyć chociażby do monitorowania przez rodziców młodszych dzieci wracających samotnie ze szkoły, transportów ważnych dóbr, osób przebywajacych pod nadzorem policyjnym.

Oferowane przez aplikację funkcjonalności również mogą podlegać ciągłemu rozwojowi i modyfikacjom. Dzięki współrzędnym geograficznym można określać adres miejsca, w którym znajdował się użytkownik. Moduł GPS potrafi dostarczyć takich informacji jak prędkość chwilowa przemieszczającego się urządzenia, wysokość nad poziomem morza, kierunek w którym się przemieszczamy.

Wszystkie wymienione powyżej elementy stwarzają możliwość implementacji nieograniczonej liczby aplikacji bazujących na omawianym systemie.

\section{Literatura}

[1] Banaszkiewicz K., Dworak M., Łata K., Repeć G.: Aplikacja mobilna "Przystanek". Informatyka, Automatyka Pomiary w Gospodarce i Ochronie Środowiska, 2/2012, s. 5-7.

[2] comarch.pl

[3] Hu W.-C., Kaabouch N., Yang H.-J., Sharif A.: Location-Based Services Design and Implementation Using Android Platforms. Midwest Instruction and Computing Symposium, Cedar Falls, IA, USA 2012

[4] Severance C.: Discovering JavaScript Object Notation. IEEE Computer Society: Computer Magazine, April 2012, p. 6-8

[5] www.comarch.pl/erp/duze-i-srednie-przedsiebiorstwa/produkty/comarch-erprozwiazania-mobilne/

\section{Inż. Marcin Bigoraj}

e-mail: bigoraj.marcin@pollub.edu.pl

Student I roku studiów magisterskich na kierunku Informatyka o specjalności technologie wytwarzania oprogramowania Wydziału Elektrotechniki i Informatyki Politechniki Lubelskiej.

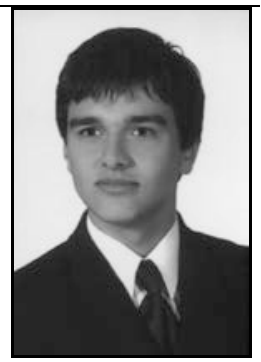

Inż. Kamil Kaźmierak

e-mail: kazmierak.kamil@pollub.edu.pl

Student I roku studiów magisterskich na kierunku Informatyka o specjalności technologie wytwarzania oprogramowania Wydziału Elektrotechniki i Informatyki Politechniki Lubelskiej.

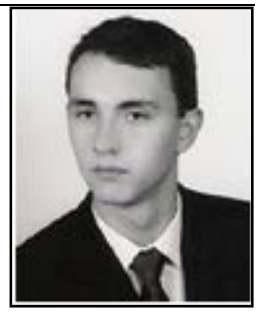

\section{Inż. Mateusz Krupa}

e-mail: krupa.mateusz@pollub.edu.pl

Student I roku studiów magisterskich na kierunku Informatyka o specjalności technologie wytwarzania oprogramowania Wydziału Elektrotechniki i Informatyki Politechniki Lubelskiej.

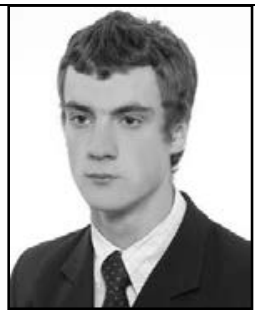

\section{Inż. Ewelina Narejko}

e-mail: narejko.ewelina@pollub.edu.pl

Studentka I roku studiów magisterskich na kierunku Informatyka o specjalności technologie wytwarzania oprogramowania Wydziału Elektrotechniki i Informatyki Politechniki Lubelskiej.

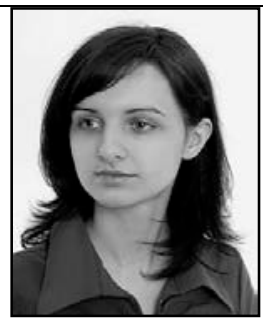

\section{Inż. Rafal Pytka}

e-mail: pytka.rafal@pollub.edu.pl

Student I roku studiów magisterskich na kierunku Informatyka o specjalności technologie wytwarzania oprogramowania Wydziału Elektrotechniki i Informatyki Politechniki Lubelskiej.

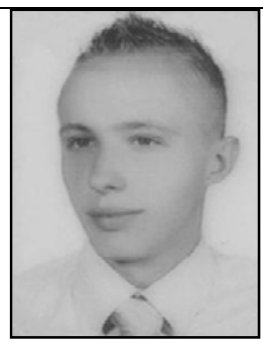

